\title{
Towards an Understanding of the Behavioral Intentions and Actual Use of Smart Products among German Farmers
}

\author{
Sirkka Schukat * and Heinke Heise
}

Citation: Schukat, S.; Heise, H. Towards an Understanding of the Behavioral Intentions and Actual Use of Smart Products among German Farmers. Sustainability 2021, 13, 6666. https://doi.org/10.3390/su13126666

Academic Editor: Claus G. Sørensen

Received: 21 May 2021

Accepted: 9 June 2021

Published: 11 June 2021

Publisher's Note: MDPI stays neutral with regard to jurisdictional claims in published maps and institutional affiliations.

Copyright: (c) 2021 by the authors. Licensee MDPI, Basel, Switzerland. This article is an open access article distributed under the terms and conditions of the Creative Commons Attribution (CC BY) license (https:// creativecommons.org/licenses/by/ $4.0 /)$.
Agribusiness Management, Department of Agricultural Economics and Rural Development, University of Göttingen, 37073 Göttingen, Germany; heinke.heise@agr.uni-goettingen.de

* Correspondence: sirkka.schukat@uni-goettingen.de

Abstract: Innovative technologies in the context of smart farming are expected to play a significant role in the adaptation of the agricultural sector to climate change and sustainable agriculture. However, the adoption of smart farming solutions, in this case so-called smart products, depends indispensably on the acceptance of farmers. For this reason, it is important to develop an understanding of what determinants are decisive for farmers in the adoption of these technologies. In order to address this research gap, farmers in Germany were surveyed via a large-scale online survey in $2020(n=523)$. Based on an extended version of the Unified Theory of Acceptance and Use of Technology, a Partial Least Squares (PLS) analysis was performed. The results indicate that hedonic motivation significantly influences farmers' behavioral intention to use smart products. In addition, behavioral intention is affected by social determinants and the personal performance expectations of smart products. Trust, as well as facilitating conditions, also has an impact on behavioral intention. Furthermore, facilitating conditions are an important determinant of the actual use behavior. In addition, use behavior is influenced by behavioral intention. It was further found that technology readiness plays a significant role in the adoption of smart products. Moderating effects of age, work experience, and farm size were identified that influence farmers' willingness to use smart products. The study holds important managerial implications for technology companies in the field of smart farming and can help develop approaches for tailored technical solutions that meet farmers' needs.

Keywords: smart farming; smart products; partial least squares; structural equation modeling; unified theory of acceptance and use of technology

\section{Introduction}

Agriculture plays a substantial role in the ongoing international debate on climate change and the sustainable use of natural resources [1]. At the same time, agriculture is not only a contributor to, but also a sufferer from, temperature increases, changing rainfall rates as well as extreme climatic occurrences [2,3]. A great proportion of the world's population still relies on agriculture as a source of income, while, as a major contributor to greenhouse gas emissions, agriculture partakes in negative impacts on the natural environment and human health [4,5]. Similar to the industrial sector, agriculture is experiencing its fourth revolution, triggered by the exponentially increasing use of information and communication technology in agriculture. Smart farming, by virtue of its technologies, is considered to pave the way to a more sustainable agriculture in crop production, livestock farming, and to the entire agribusiness supply chain [6,7]. In the field of crop farming, autonomous robotic vehicles and unmanned aerial vehicles with autonomous flight control have been developed that can collect and process crop information [8]. Virtual fencing technologies are applied in livestock farming to manage livestock herds based on remote sensing signals and sensors or actuators attached to the animal [9].

One development of the fourth industrial revolution, and thus also of smart farming, is the Internet of Things (IoT), in which all varieties of devices are connected and interact 
with each other via local and global, often wireless, network infrastructures. Known as smart products, these devices serve as a link between the virtual and physical worlds, can respond in real time and make partially autonomous decisions. [10]. Smart products differ from traditional computers, for example, due to haptic user interfaces based on gesture identification or acceleration sensors. They are characterized by their capability to use specific technologies to sense and communicate information about themselves, their condition, and the context that surrounds them [11]. These features give them the ability to act proactively and in real time with respect to their internal status and context, adapt to different situations, interact with other smart products, and communicate information across lifecycle boundaries [12]. Technically, various requirements must be met, including the connectivity of the products, for example via network technologies such as $\mathrm{Wi}-\mathrm{Fi}$, followed by sensor technology to detect the user environment, as well as sufficient computing power [12]. Smart farming requires real-time assistive reconfiguration capabilities to perform agile actions, especially in the event of sudden changes in farm operating conditions [13].

All in all, the advantages of smart farming are assessed as very meaningful. With regard to climate change and sustainability, it is assumed that smart farming can reduce the ecological footprint of agriculture and mitigate greenhouse gas emissions, both in crop production and livestock farming [14]. In addition, it is assumed that smart farming can make business more profitable for farmers, on the one hand by reducing the use of resources, and on the other hand by minimizing risks thanks to high-precision geographical data [6]. Another effect of smart farming is expected to enhance consumer acceptance of agricultural products. By reducing the use of fertilizers and pesticides, a higher product quality could be achieved, which in turn could lead to higher prices, while at the same time enabling the transparency of production through digital tracking of agricultural products [15].

Contrary to the positively perceived aspects, however, some hurdles remain, which include data security, especially data sovereignty. The risk of potential data misuse poses legal and ethical challenges for regulation and surveillance [16]. The potentially high cost of implementing smart products for farmers combined with limited skills and knowledge can also pose a daunting barrier to successful adoption [17]. Thus, for example, the question arises as to whether access to the latest technologies will be limited only to large and industrialized farms. Another challenge will be to align farmers' competencies and capabilities with these new technologies, as the digitization of agriculture expands farmers employment opportunities [6].

Obviously, however, one condition for benefiting from the promise of smart products is their use by farmers. The ultimate value of technological innovations, therefore, depends on their acceptance. According to a recent representative study, $82 \%$ of farms in Germany already use digital technologies or applications [18]. Those that are particularly prevalent include GPS-controlled agricultural machinery (45\%), intelligent feeding systems (46\%), mobile applications $(40 \%)$, and the intelligent and site-specific application of crop protection agents or fertilizers (32\%). Political support is mainly directed at research projects, e.g., in the form of Digital Experimental Fields [19]. Previous studies have increasingly focused on technologies in the context of precision agriculture. For example, the relevance of compatibility between components of precision farming technologies [7], the role of farm characteristics [20], and the socio-demographic characteristics of farmers, such as education or age [21,22], have been investigated. In the area of smart farming, the adoption of Internet of Things applications in Iran has been studied [23]. For Germany, the adoption and use of smartphones among farmers was investigated [24]. Thus far, empirical studies explicitly investigating the acceptance of smart products on a more general basis in German agriculture are rare. To close this research gap, this article aims to investigate the determinants of farmers' behavioral intention and use behavior regarding smart products. Identifying the determinants helps to understand how behavioral intention and the use behavior of smart products among farmers is influenced and how adoption can be fostered. 
To achieve this aim, farmers in Germany were surveyed regarding their attitudes and their actual use of smart products. After deriving the hypotheses, the data were analyzed using an extended version of the Unified Theory of Acceptance and Use of Technology 2 (UTAUT 2) to evaluate which determinants influence farmers' behavioral intention and use behavior regarding smart products.

\section{Conceptual Framework}

The UTAUT 2 model is used to examine the farmer adoption of smart products and the factors that drive behavioral intention and use behavior. This model is an extended version of the UTAUT, which was introduced as a conceptual framework for studying decision makers' intentions to use or not use a new form of technology or system, such as smart products in the context of smart farming [25]. It contains seven key constructs (performance expectancy, effort expectancy, social influence, facilitating conditions, hedonic motivation, price value, and habit) that determine the behavioral intention to use the technology [25]. During a literature review, and based on the results of previous studies, two additional constructs (trust and technology readiness) were added to the original UTAUT 2 model to adapt the model to the research question of this study. These two constructs are explained in the derivation of hypotheses section below. Further, some moderating influences, such as age, gender, and experience, were identified in the original UTAUT model [25]. Since farm size was found to have a positive impact on the adoption of precision agriculture technologies based on economies of scale considerations [20], farm size is also believed to have a moderating effect on behavioral intention and usage behavior of smart products. Figure 1 summarizes all of the hypotheses of this study in one model. The two constructs and the moderating effect added to fit the UTAUT 2 model to this study are highlighted in bold. The determinants are explained below, followed by the derivation of the hypotheses.

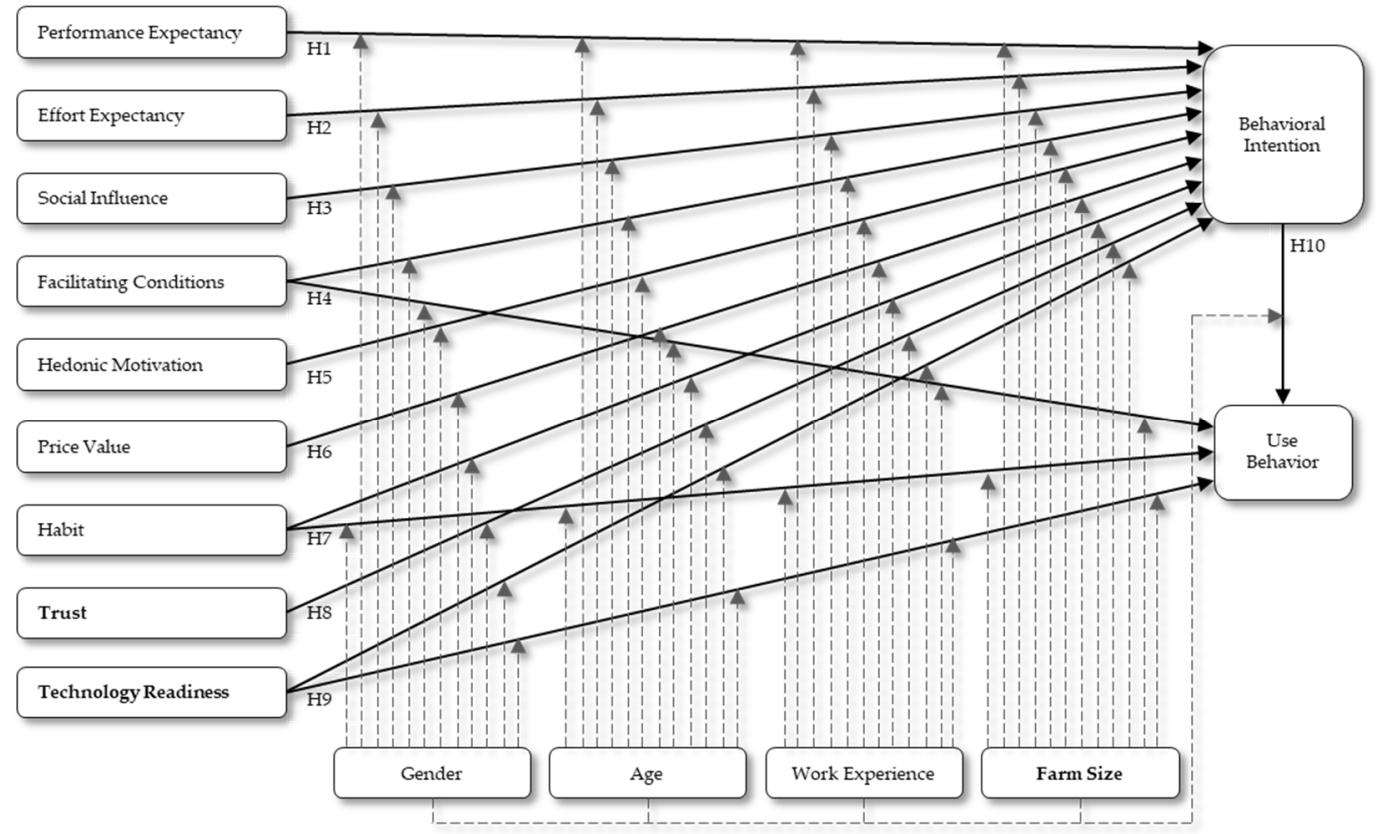

Figure 1. Model used in the partial least squares (PLS) analysis according to UTAUT 2 [26]. Copyright (C) 2003, Regents of the University of Minnesota. Reprinted by permission.

Performance expectancy is defined as the degree to which an individual expects that using a system or technology, in this case smart products, will be beneficial and provide support and a relative advantage [26]. In agriculture, economic performance plays an important role in the adoption of technologies or systems. Economic aspects are considered as one of the main reasons for farmers to adopt smart farming technologies [13]. Furthermore, the possibility of delivering a contribution to a more sustainable agriculture is perceived as 
an advantage of smart products in the overarching context of smart farming [6]. However, the possibilities for facilitating the monitoring and management of livestock and crops, as well as the reduction and increasing flexibility of working hours, are likewise perceived as advantages $[27,28]$. Gender and age appear to play a moderating role in the relationship between performance expectancy and behavioral intention. Studies on gender differences show that young men are more achievement-oriented than women [26]. In addition, farm size is assumed to be positively correlated with overall farm performance [29]. For this reason, the following hypotheses can be derived for this study:

Hypothesis 1 (H1). Performance expectancy has a significant influence on behavioral intention.

Hypothesis 1a (H1a). Gender, age, work experience, and farm size have an impact on the relationship between performance expectancy and behavioral intention.

The determinant effort expectancy is defined as the expected effort when using a system or technology, whereby the expected effort is often perceived as higher for a new system in the initial phase. The expected effort includes both financial aspects and time. Additional effort is often associated with learning how to use and operate a system or technology rather than with the use itself [30]. Another aspect that leads to a high expected effort is unpredictable monetary costs that could arise, for example, from technology adaptations [31]. Elderly women with little work experience are expected to rate expected effort higher than men. Therefore, gender, age, and work experience might play a moderating role on the relationship between effort expectancy and behavioral intention [25]. The perceived effort to adopt a new system or technology increases with age, as the time required for the learning process is higher [32]. Small farms tend to lag behind larger farms due to economies of scale, productivity differences, market prices for inputs, and the transaction costs for evaluating and acquiring new technologies [33]. Therefore, farm size is assumed to moderate the relationship between expected effort and behavioral intention. From this, the following hypotheses for the work can be derived:

Hypothesis 2 (H2). Effort expectancy of the farmers has an influence on behavioral intention.

Hypothesis 2a (H2a). Gender, age, work experience, and farm size have an impact on the relationship between effort expectancy and behavioral intention.

Social influence is determined by important people, such as friends, colleagues, and relatives, who influence an individual to use a system or technology. Social pressure, which emanates from the media or politics, is also considered. A study examining the social influence of colleagues, friends, and family on strategic farm decisions identified a contribution of social influence related to issues such as business development, sustainable agriculture, and conservation practices [34]. The social environment, such as friends and family, influences the operational development of a farm to a certain extent. In addition, the experience of a farmer's colleagues with new technologies has been found to have a significant influence on a farmer's future use [35]. Furthermore, family members have a great influence on strategic decisions for the development of a farm [36]. In the organizational environment, research suggests that older employees are more likely to conform to a majority opinion [37]. Further, it is assumed that women tend to be more people-oriented, whereas men tend to be more independent and self-confident [38]. Inexperienced users of technology tend to follow the views of others and use the technology to obtain positive reactions from important peers, even if they lack a positive reaction to the technology itself [39]. Therefore, social influence is potentially moderated by age, gender, work experience, and farm size. From this, the following hypotheses for the work can be derived:

Hypothesis 3 (H3). Social influence of the farmers has an influence on behavioral intention. 
Hypothesis 3a (H3a). Gender, age, work experience, and farm size have an impact on the relationship between social influence and behavioral intention.

The construct of facilitating conditions describes to which degree the respondents believe that an organizational and technical infrastructure exists on a farm that facilitates the use of the system. The construct of facilitating conditions thus encompasses those operational prerequisites that enable the use of smart products in the first place. Facilitating conditions have an influence on both the behavioral intention and the adoption itself [26]. They include the availability of external resources such as fast stationary or mobile internet and the capacity of the power network [40]. It further includes general IT systems such as internal networks and specific IT systems that are required to support the system [41]. Another factor is the extent to which organizational farm processes are aligned with implementation challenges and can be modified to address new system requirements [42]. This also includes the capability of acquiring the necessary technical skills, knowledge, and workforce to implement technology [41,43]. Elderly employees with more years of work experience are assumed to place greater value on receiving assistance and support when adopting technology [37]. Men tend to rely less on facilitating conditions when considering the use of a new form of technology, while women tend to attach more importance to external supporting factors [44]. In addition, it is assumed that larger farms possess the organizational prerequisites for the adoption of new technologies, e.g., due to the economies of scale [45]. From this, the following hypotheses for this study are derived:

Hypothesis 4 (H4). Facilitating conditions have an influence on behavioral intention.

Hypothesis 4a (H4a). Gender, age, work experience, and farm size have an impact on the relationship between facilitating conditions and behavioral intention and on the relationship between the facilitating conditions and use behavior.

Hypothesis $4 \mathbf{b}(\mathbf{H} 4 \mathbf{b})$. Facilitating conditions have an influence on use behavior.

Hedonic motivation is defined as the amusement that results from the use of the system. It describes the respondent's motivation to use a system or technology. In the context of precision agriculture, for example, strict environmental laws, public concerns about excessive application of agrochemicals, and the economic benefits from reduced farm inputs and improved farm management efficiency can serve as motivators for the adoption of new technologies [46]. However, hedonic motivation in particular refers to an individual's positive motivations and is characterized by a special multidimensionality, which applies to both monetary and non-monetary aspects [47]. Furthermore, age and gender are related to hedonic motivation in that young males are more likely to seek novelty and innovativeness in the early stages of using a new form of technology [48]. Further, as experience increases, the attractiveness of novelty, which contributes to the effect of hedonic motivation on technology use, will decrease [25]. In addition, farm size in conjunction with risk aversion or risk perception seems to play a role in farmers' technology adoption behavior [21]. Hedonic motivation is therefore potentially moderated by age, gender, and work experience [25]. The following hypotheses are established:

Hypothesis 5 (H5). Hedonic motivation significantly influences behavioral intention.

Hypothesis 5a (H5a). Gender, age, work experience, and farm size have an impact on the relationship between hedonic motivation and behavioral intention.

Price value represents the trade-off between the benefits of using a system or technology and the monetary costs of using it. If the perceived benefits exceed the monetary costs, the respondent is more likely to use the system. In this context, price value has a positive influence on the behavioral intention to use smart products. Farmers engage in 
a business with their farm and are required to generate profit for their farm in order to remain competitive [36]. The price value that farmers receive for adopting a system or technology is an important factor from the farmers' perspective. The perceived complexity of new technologies is partly attributed to the required change in the way farmers work, moving from experience-based decisions to data-driven processes, which can lead to uncertainty about the potential costs and benefits of the technology $[17,49,50]$. Men tend to act competitively and make decisions based on selective information, while women operate more dependently and cooperatively; therefore, they pay more attention to prices and act more cost-conscious than men, a tendency that is reinforced with age and experience [51]. Since investment behavior differs between small and large farms, it is assumed that this also applies to price value [29]. The following hypotheses are set for the study:

Hypothesis 6 (H6). Price value has a significant influence on behavioral intention.

Hypothesis 6a (H6a). Gender, age, work experience, and farm size have an impact on the relationship between price value and behavioral intention.

Habit is defined as the extent to which people tend to perform behaviors automatically due to learning. Habit is assumed to influence both behavioral intention and use behavior [25]. Experience must also be taken into account, since the relationship between experience and habit is formed and reinforced by repeated behavior [52]. In the context of this study, habit refers to how quickly the use of smart products becomes a routine for the farmer and proceeds as an automated behavior. Since experience is considered to be a condition for habit formation and different individuals may form different levels of habit over a period of time, experience is expected to exert a moderating effect on the relationship between habit and behavioral intention [25]. Studies showed that once older people have formed a habit through repeated use of a particular technology, it is difficult for them to override their habit to adapt to a different environment, as aging leads to a decreasing capacity to process information. [25]. In addition, men are more likely to rely on habits acquired through usage experiences to determine their behavioral intention [53]. Since farmers differ in terms of their behavior, e.g., risk perception, and habits are influenced by experience, it is assumed that farm size also has an influence on farmers' habits [54]. The following hypotheses are set for the study:

Hypothesis 7 (H7). Habit has a significant influence on behavioral intention.

Hypothesis 7a (H7a). Gender, age, work experience, and farm size have an impact on the relationship between habit and behavioral intention.

Hypothesis $7 \mathbf{b}(\mathbf{H 7 b})$. Habit has a significant influence on use behavior.

In order to adapt the UTAUT 2 model to the research question of this study, the following two additional constructs were integrated into the model: trust and technology readiness. Earlier study findings that addressed the role of trust and readiness in the context of technology acceptance among farmers motivated the inclusion of these constructs [55-57]. Trust is an important determinant for a successful business relationship in the agricultural branch. Empirical research suggests, for example, that low rates of technology adoption are more often due to a lack of trust than cost. Even if farmers learn of the potential benefits of a technology, some lack confidence that the new technology will function as it is purported to [58]. Simultaneously, improving trust by believing that the technology will deliver the expected results, as well as understanding the process to achieve a goal with the technology if a process fails, is believed to lead to higher adoption rates of the technology [59]. Similar findings emerged in an investigation of farmers' acceptance regarding the adoption of innovative green technologies [60]. Therefore, trust was supplemented as an additional construct to the original model. In addition, it is assumed that women often have more 
confidence than men and that confidence decreases with age [61]. Furthermore, in the case of cloud technologies, experience has been found to influence the relationship between trust and behavioral intention; therefore, a moderating effect is expected here as well [62]. Farm size also appears to moderate this relationship [63]. Altogether, the study results in the following hypothesis:

Hypothesis 8 (H8). Trust has a significant influence on behavioral intention.

Hypothesis 8a (H8a). Gender, age, work experience, and farm size have an impact on the relationship between trust and behavioral intention.

A further construct added to the model is technology readiness. Technology readiness comprises an individual's readiness to personally assess technological progress as an added value. It includes both personal competence beliefs and control beliefs, i.e., a person's belief that he or she is competent in using a particular technology [64]. In this context, personal interest in technical innovations and user involvement play a predominant role [64]. It is assumed to directly influence both behavioral intention and use behavior. This hypothesis is based on studies that have already identified technology readiness as a factor in technology adoption, albeit not in direct relation to smart products [65-67]. Technology readiness, therefore, encompasses the extent to which an individual is personally prepared for technology implementation. If farmers believe that a system or technology matches their needs and is compatible with their personal environment, it is considered likely that the technology will be adopted because they consider it to be a positive investment [68] Furthermore, the perception of safe handling of smart products also represents technology readiness, as it reflects the self-concept of an individual's own abilities as well as the extent of the individually perceived controllability of the technology $[13,64]$. In the initial stages of using a new form of technology, young men are more inclined to explore for novelty and innovation, whereas elderly people tend to exhibit fear of loss of control and incompetence $[44,48,69]$. Other studies focused on how experience influences technology readiness, suggesting that the higher a person's technology-related experience is, the higher his or her technology readiness is [70]. The following hypotheses are derived:

Hypothesis 9 (H9). Technology readiness has a significant influence on behavioral intention.

Hypothesis 9a (H9a). Gender, age, work experience, and farm size have an impact on the relationship between technology readiness and behavioral intention and on the relationship between the facilitating conditions and use behavior.

Hypothesis $9 \mathbf{b}(\mathbf{H 9 b})$. Technology readiness has a significant influence on use behavior.

Usage behavior describes the actual use of a system or technology and is assumed to be influenced by behavioral intention. Behavioral intention contains the intention or non-intention to use smart products. It reflects farmers' attitudes toward smart products, with a certain influence of moderators on the strength of the relationships between the independent variables and behavioral intention. It is expected that behavioral intention has a significant positive influence on technology usage [26,71]. Older and less experienced persons do not adapt favorably to technological change because the ability to acquire new technical skills diminishes with age [72]. Since women and men encode and process information on the basis of different socially constructed cognitive structures, which in turn contribute to the use behavior of technology, it is assumed that gender has a moderating effect [44]. In addition, farm size influences the use of technology as they are evaluated in terms of their intended use [73]. Therefore, the following hypotheses are put forward:

Hypothesis 10 (H10). Behavioral intention has an influence on use behavior. 
Hypothesis 10a (H10a). Gender, age, work experience, and farm size have an impact on the relationship between behavioral intention and use behavior.

\section{Materials and Methods}

\subsection{Sampling and Analysis Methods}

The data for this study were collected in the period from June to August 2020 via a standardized and anonymized online survey. A total of 523 farmers from Germany participated in the survey. Before the official activation of the online questionnaire, experts from agricultural economic research as well as farmers (livestock and crop professional farms) pre-tested the survey for one week in order to prevent misunderstandings within the questionnaire. Contacting the farmers was accomplished via different channels. The inquiries with a request to forward the questionnaire were directed to the Lower Saxony Chamber of Agriculture, the regional offices of the German Farmers' Association, the social media websites of relevant agricultural magazines (Topagrar, Farm Food Future, Hoftierarzt), as well as private networks such as Xing or Facebook. The questionnaire was preceded by a definition of smart products to ensure a common understanding among the participating farmers ("More and more devices are connected to the internet. Smart products collect data via corresponding sensors, evaluate them and forward them via the Internet or receive data from other smart products. The "intelligence" of these products means that they perform tasks independently and communicate with other products."). In addition, the following three examples were mentioned, and their functionality was explained: smart phone, smart ear tag, and smart pig counter. The questionnaire was divided into three parts. In the first part, farmers were asked about their socio-demographic and farm characteristics, e.g., age, gender, education, work experience, farm size. The second part consisted of 55 statements designed to determine farmers' attitudes toward smart products. The given statements required responses based on five-point Likert scales ranging from "strongly disagree" to "strongly agree" and serve as indicators of the constructs analyzed in the UTAUT 2 model. The third part consisted of 10 statements designed to determine farmers' perceptions of the national adoption of smart products. Furthermore, a control question to ensure the response quality was included.

A modified UTAUT 2 model was used for the analysis. The constructs of the model, whose relationship with behavioral intention and use behavior is intended to be examined, are so-called latent variables. Latent variables are not directly observable and must therefore be described through empirical indicators [74]. In this study, a partial least squares (PLS) analysis was adopted. PLS analysis is used to determine the interrelationships of latent variables, which are the determinants of behavioral intention and usage behavior of smart products, in the form of the extended UTAUT 2 model. In a reflective measurement model, as presented in this article, it is assumed that the indicators are caused by the latent variables [74]. The indicators are linked to the associated latent variables through a simple regression. Finally, the model examines the relationships between the latent variables. In order to examine the moderating effects of age, gender, work experience, and firm size, a multi group analysis (MGA) is applied. The MGA offers the possibility to subdivide a moderator into groups and to examine the influence continuously throughout the model [75]. The groups were allocated to provide comparable group sizes. SmartPLS 3.3.2 analysis software was used to conduct the PLS analysis [76]. IBM SPSS Statistics 26 software was applied for the descriptive analysis of the questionnaire.

\subsection{Quality Criteria of the Measurement Model}

The evaluation of the measurement model provides information on the extent to which the theoretically assumed measurement and structural model are represented by the empirically estimated results. The most important assessment criteria for the measurement model are the internal consistency reliability, convergence validity, and discriminant validity. First of all, the internal consistency reliability is evaluated by the composite reliability 
and Cronbach's alpha values. The composite reliability serves as the first step in order to test the quality of the measurement model and provides information on whether a specific indicator is sufficient to describe the assigned construct. Values for composite reliability that are between 0.6 and 0.7 are considered acceptable in exploratory research. A value of 0.7 ensures that at least $50 \%$ of the variance of the indicator is explained by the assigned construct [77]. To verify whether the set of indicators adequately describes the assigned construct, Cronbach's alpha values are determined [78]. These values should ideally exceed 0.7 [79].

Convergence validity describes the extent to which a measurement is positively correlated with an alternative measurement of the same construct. For testing, the loadings of the indicators as well as the average variance extracted (AVE) are considered. The indicator loadings should normally exceed a value of 0.7 . However, indicators with lower charges are retained if they contribute appropriately to content validity and are not below 0.4 [80]. The AVE is considered to be the mean of the squared loadings of all of the indicators related to the construct. An AVE of more than 0.5 indicates that the construct explains, on average, more than half of the variance of its indicators [81]. Values of 0.6 or more represent a good construct reliability [82].

Discriminant validity of a measurement model describes the extent to which a construct actually differs from other constructs along empirical standards and is measured by various criteria. The first criterion pertains to the cross-loadings of the indicators, which implies that the loading of an indicator on its associated construct should be higher than any of its cross-loadings on any other construct [81]. Cross-loadings that are higher than the actual indicator loadings on the associated construct indicate a lack of discriminant validity. The second approach to assessing the discriminant validity of construct measures is the Fornell-Larcker criterion. It compares the square root of the AVE with the correlations of the latent variables, where the square root of the AVE of each construct should be greater than its highest correlation with any other construct [83]. Nevertheless, neither the crossloadings nor the Fornell-Larcker criterion are considered to be truly reliable for identifying discriminant validity problems [84]. For this reason, the third criterion considered is the heterotrait/monotrait ratio (HTMT) of the correlations. The HTMT criterion describes the relationship between the following two types of correlations: the correlations between indicators that measure different constructs and the correlations between indicators that each measure their own construct. If the pathway model contains constructs that are conceptually very similar, an HTMT threshold of 0.9 should not be exceeded; if the constructs in the pathway model are conceptually more different, an HTMT threshold of 0.85 applies [84]. An HTMT value higher 0.9 indicates a lack of discriminant validity. Table 1 gives an overview of the quality criteria for the measurement model.

Table 1. Quality criteria with threshold values of reflective measurement models [81,84].

\begin{tabular}{cc}
\hline Internal consistency reliability & $\begin{array}{c}\text { Composite reliability }>0.6[82] \\
\text { Cronbach's alpha }>0.7[79]\end{array}$ \\
Convergence Criteria & $\begin{array}{c}\text { Indicator loading }>0.7[77] \\
\text { AVE }>0.5 \text { [81] }\end{array}$ \\
\hline Discriminatory Validity & $\begin{array}{c}\text { Cross loadings }<\text { loadings on the associated construct [81] } \\
\text { Fornell-Larcker criterion }<\text { square root of AVE [82] } \\
\text { HTMT of the correlations }<0.9 \text { [84] }\end{array}$ \\
\hline
\end{tabular}

AVE, average variance extracted; HTMT, heterotrait/monotrait ratio.

\subsection{Quality Criteria of the Structural Model}

Evaluation of the structural model includes examining the predictive ability of the model and testing the relationships between the constructs. The structural model is a representation of the possible factors influencing the variable to be explained and thus examines the relationships between the variables [75]. Initially, collinearity is assessed 
because the estimation of path coefficients in the structural model is based on regressions between each endogenous latent variable and its driver constructs, and the path coefficients are biased when critical levels of collinearity exist between the driver constructs. Tolerance levels below 0.2 in the driver constructs are considered to be an indicator of collinearity [80].

The path coefficients of the structural model can be interpreted in the same way as the beta coefficients of a regression analysis. The coefficients are checked for their extent and significance using t-statistics. For this study, the path coefficients' significance is determined by means of the non-parametric bootstrapping method [85]. The bootstrapping method generates subsamples that are randomly drawn from the data set. These are covered before each new path. The subsamples are used to estimate the PLS path model. The parameter's estimates (for example loadings and path coefficients) of the subsamples are used to calculate the standard deviation. This results in the t-values for the significances of the parameters $[81,86]$. The path coefficients should exceed a value of 0.2 to be considered a meaningful influencing factor [81]. In some cases, path coefficients above 0.1 are accepted as having a considerable influence [87].

The coefficient of determination, $R^{2}$, is a measure of the model's predictive performance and is calculated using the squared correlation between the actual and predicted values for a specific endogenous construct. The coefficient thus represents the combined effects of all of the exogenous latent variables on the endogenous latent variable [88]. The larger $\mathrm{R}^{2}$ is, the higher the proportion of the explained variance is [81]. For some scientists, an $R^{2}$ with a value of more than 0.25 is considered acceptable [89]. This ensures that at least $25 \%$ of the variance of the endogenous variable is explained by the influencing factors.

In addition to evaluating the $R^{2}$ values of all the endogenous constructs, the $f^{2}$ effect strength tests whether an exogenous construct exerts a substantial influence on an endogenous construct. Therefore, the change in the $\mathrm{R}^{2}$ value for a specific endogenous construct is determined for a case where the exogenous construct is excluded from the structural model [80]. For the assessment of $\mathrm{f}^{2}$ values, $0.02,0.15$, and 0.35 represent small, medium, and large effects of the exogenous latent variables, respectively, while effect strengths of less than 0.02 indicate that no effect exists [90].

The predictive validity of the model can be determined using the Stone-Geisser test $[91,92]$. The test is determined using the so-called blind folding procedure, which systematically assumes that part of the raw data matrix is missing in the parameter estimation [85]. The procedure removes the data and treats them as missing values in the parameter estimation. This shows how accurately the data can be reconstructed by the model. $\mathrm{A} \mathrm{Q}^{2}>0$ implies that the model has a good predictive validity [81]. Table 2 gives an overview of the quality criteria for the structural model.

Table 2. Quality criteria with threshold values of the structural model [80].

\begin{tabular}{cc}
\hline Collinearity & Collinearity $<0.2 \mathrm{f}^{2}>0.02$ \\
\hline Relevance and significance of the path coefficients & $\begin{array}{c}\mathrm{t} \text {-value } \geq 1.65[80] \\
\mathrm{p} \text {-value } \leq 0.05[80]\end{array}$ \\
\hline Coefficient of determination (R2) & $\mathrm{R} 2>0.25[89]$ \\
\hline f2 effect strengths & $\mathrm{f} 2>0.02[90]$ \\
\hline Predictive relevance (Stone-Geisser's Q2) & $\mathrm{Q} 2>0[81]$ \\
\hline
\end{tabular}

The UTAUT model also includes the moderating effects on the relationship between the constructs, behavioral intention and use behavior. The effect must be taken into account when calculating the model. A moderator is a qualitative or quantitative variable that affects the direction or strength of a relationship between an independent variable and a dependent variable [93]. For this model, gender, age, work experience, and farm size are considered to be moderators that influence the relationships between each construct, and behavioral intention and use behavior. In this study, the MGA is well suited for examining continuous moderating effects throughout the model. For continuous moderators, such 
as age, work experience, and farm size, using the moderating effects in SmartPLS 3 is reasonable [77]. The PLS-MGA calculates two separate bootstraps for the groups to be compared [94].

\section{Results}

\subsection{Sample Description}

The sample ( $n=523)$ is composed of $77.1 \%$ men and $22.9 \%$ women. According to the relative composition of the population of farmers in Germany, the proportion of women is about $36 \%$, thus women remain slightly underrepresented in this study [95]. Of the respondents, $21.6 \%$ are older than 55 , slightly underrepresenting the average age of employees, as one-third of all agricultural employees in Germany are older than 55 [95]. Of the respondents, $36 \%$ hold an agricultural apprenticeship, attended a special agricultural college, or own a Meister (master farmer) degree. In this case, the average of the educational distribution of German farmers, where $68 \%$ have the above types of educational qualifications, has fallen rather short [95]. Moreover, $44.4 \%$ of the respondents in the sample hold a university degree. Overall, the proportion of farmers with a university degree in Germany amounts to $12 \%$, which leads to an overrepresentation of academics [95]. The majority of respondents live in Lower Saxony, North Rhine-Westphalia, and Bavaria. The same federal states have the highest share of professional farms in total farms in Germany [96]. With an average farm size of 374.12 hectares, large farms are substantially overrepresented, as the national average for farms with 200 to 499 hectares is about $16.3 \%$ [97]. The study cannot be considered representative, as the distribution in the aforementioned criteria differs from the distribution of the German population. For further information on the profiles of the respondents, please refer to Appendix A.

\subsection{Results of the PLS Analysis}

A PLS analysis was applied for the calculation and evaluation of the extended UTAUT model. The PLS algorithm analyzes the relationship between latent constructs in the UTAUT model. Latent constructs in the UTAUT model are considered unobservable and are characterized by empirically sampled indicators. To determine the significance of item loading, a bootstrap procedure with 5000 subsamples was performed. All of the external loadings of the indicators exceed the required value of 0.6 and 0.7 , respectively. The constructs that remained in the model after the measurement model's quality criteria were verified consisted of performance expectancy, effort expectancy, social influence, facilitating conditions, hedonic motivation, price value, trust, technology readiness, behavioral intention, and use behavior (see Appendix B). Since the construct habit failed to meet the quality criteria of the measurement and structural model, in particular discriminant validity within the HTMT of the correlations, it was removed from the model.

To assess the reliability of the constructs, composite reliability and AVE were calculated. All of the AVE and composite reliability values are above the recommended threshold, suggesting an acceptable construct reliability. Appendix $C$ shows the construct reliability results. To assess discriminant validity, cross-loadings, the Fornell-Larcker criterion, and the HTMT ratio were examined. The HTMT ratio is considered to be the most reliable of the above criteria and describes the relationship between the following two types of correlations: the correlations between indicators that measure different constructs and the correlations between indicators that each measure their own construct. All of the measures of discriminant validity meet the recommended threshold values (see Appendix D).

Initially, examination of the structural model revealed that there was no critical level of collinearity. Figure 2 shows the results of the path coefficients calculated with the PLS algorithm. The paths of performance expectancy, social influence, facilitating conditions, hedonic motivation, trust, and technology readiness have a significantly positive influence on behavioral intention. Furthermore, facilitating conditions, technology readiness, and behavioral intention have a significantly positive influence on use behavior. Technology readiness, hedonic motivation, and social influence have the strongest influence on behav- 
ioral intention, whereas technology readiness and behavioral intention have the strongest influence on use behavior. The path coefficients of effort expectancy $(-0.057)$ and price value (0.042) are very low and show no significance. These path coefficients are not truly of interest for interpretation, even if they were significant, since they are below 0.1 [77]. The coefficient of determination $\mathrm{R}^{2}$ reaches a value of $63.1 \%$ for behavioral intention and $35.5 \%$ for use behavior. To examine the moderating effect of gender, age, work experience, and farm size, the MGA was applied. Moderators can affect the strength and direction of a relationship in the model [93]. The MGA is suitable because it allows a moderator to be continuously evaluated in the full model [75].

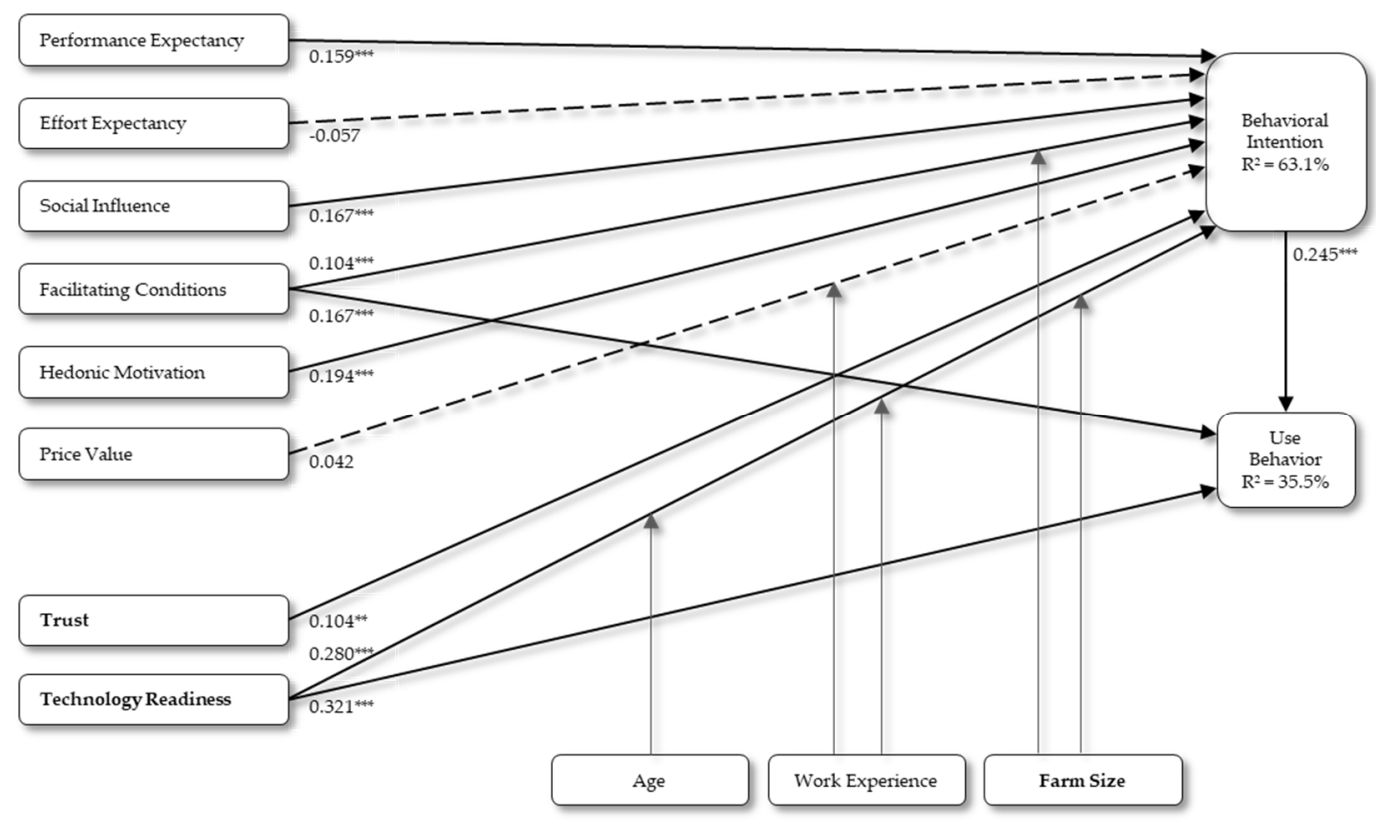

Figure 2. Results of the PLS analysis: Determinants of behavioral intention and the use behavior of smart products. The values are presenting the path coefficients. Significance level: ${ }^{* *} p \leq 0.01,{ }^{* * *} p \leq 0.001$; Broken/missing line: not significant; $\mathrm{n}=523$. Adapted from [26]. Copyright $@$ 2003, Regents of the University of Minnesota. Reprinted by permission.

No significant effects could be identified for the gender moderator. Farm size has a moderating effect on the relationship between facilitating conditions and behavioral intention, whereby its impact is stronger for farms with more than 140 hectares. Furthermore, farm size has a moderating effect on the relationship between technology readiness and behavioral intention, with the effect here being stronger for farms up to 140 hectares. Both of these moderating effects are significant (see Appendix E). Age has a moderating effect on the relationship between technology readiness and behavioral intention. The effect is significant and stronger for the group of younger respondents up to 30 years old in comparison to farmers aged 31 years and older (see Appendix F). Work experience has a moderating effect on the relationship between price value and behavioral intention. The effect of price value is significant and is strongest for the group of respondents with over 30 years of work experience, compared to all of the other farmers. Furthermore, work experience has a moderating effect on the relationship between technology readiness and behavioral intention. The effect of technology readiness is significant as well and is strongest for the group of respondents with up to 10 years of work experience, compared to farmers with 11 or more years of work experience (see Appendix G). It becomes clear that 13 of the 23 hypotheses can be confirmed.

\section{Discussion}

The adoption of smart farming solutions, in this case so-called smart products, depends indispensably on the acceptance of farmers. Therefore, the determinants that influ- 
ence farmers' behavioral intention and use behavior with regard to smart products were investigated. Statements such as "I would use smart products if there were advantages for animal health, animal welfare, animal behavior or hygiene conditions in the farm" were supported by the majority of respondents $(84.3 \%, \mathrm{n}=441)$. The statement "I plan to use smart products on my farm in the future" was still affirmed by $61.5 \%(\mathrm{n}=322)$ of respondents. This value contrasts the study results that indicate a hesitant adoption of smart farming technologies among farmers $[60,98,99]$. In other studies, the majority of German farmers are considered to be sympathetic towards the adoption of innovative technologies [100]. This could be explained by the fact that new technologies in the field of smart farming may have become particularly widespread in the last few years. In the course of the evaluation, several influencing factors were discernible.

First, the farmers' technology readiness has both the strongest influence on their intention to use smart products (0.280) and on their use behavior (0.321), which makes it the strongest determinant of smart product use. If a farmer features the technological readiness, the adoption of smart products becomes more probable. One of the few studies to examine technology readiness for IoT implementation on farms also emphasizes the importance of technology readiness for adoption [57]. The present study identified a moderating effect of farm size on technology readiness, such that it exerts a greater influence on smart products behavioral intention for large-scale farms of 140 hectares or more. Other studies have already demonstrated that the adoption of smart farming technologies is positively correlated with farm size $[19,21,27]$. Furthermore, technology readiness is moderated by the farmer's work experience; thus, the influence of technology readiness is stronger for farmers with less than 30 years compared to farmers with more than 30 years of work experience. A moderating effect on the relationship between technology readiness and behavioral intention was also identified for age, which is higher for farmers up to 30 years of age than for those over 30 . The results are also consistent with previous research findings regarding technology adoption on farms [101,102].

Hedonic motivation was identified as the second strongest determinant (0.194). Thus, the farmer's motivation plays a major role in the intention to use smart products. Relevant motivators within the scope of the model presented in this study are technology affinity on the one hand and sustainability aspects on the other. The statement "I enjoy testing new technologies" was agreed to by $79.7 \%(n=417)$ of respondents, either somewhat or completely. Previous studies have demonstrated that innovativeness and technology affinity have a significant positive effect on the adoption of precision agriculture technologies $[7,103]$. Regarding the statement, "I would like to produce more sustainably by using resources optimally with the help of digitalization", $80 \%(n=418)$ of the respondents agreed rather or completely. Intrinsic motivation plays an important role in transforming organizations into ecologically sustainable businesses [104]. With respect to precision agriculture, it has been shown that younger farmers are more willing to implement new technologies due to their stronger interest in them [105]. At the same time, the probability of farmers using a computer decreases with age [106]. This study could not detect a significant moderating effect of age on the relationship between hedonic motivation and behavioral intention.

Social influence was identified as the third strongest determinant (0.167). Consequently, the farmer's social environment plays a crucial role in the acceptance and behavioral intention regarding smart products. The factors influencing the farmers' attitudes and decisions related to the adoption of technological innovations have been extensively studied. Among other factors, the social environment, including family but also colleagues, plays a major role in many of the decisions that farmers face $[35,107]$. It can be assumed that farmers discuss the implementation of new technologies in the context of smart products with family members. The general attitude of farmers is further influenced by the social environment [34]. For farmers, familiar social contacts and interaction with colleagues are particularly important for successful technology implementation, as their learning pro- 
cesses are primarily socially oriented [108]. Thus, the present results support the findings of previous studies.

Performance expectancy was identified as another determinant (0.159) within the model. The statement, "smart products can relieve me of certain work processes" was agreed with, from somewhat to completely, by $81.9 \%(n=428)$ of the respondents. Some studies have argued that technologies in agriculture are often insufficiently adapted to the context and needs of farmers, thus the decision not to adopt technology can be characterized as rational because it contradicts the farmer's performance expectation [109,110]. Expected performance in terms of profit favors the farmer's adoption of technology because of the prospect of higher yields as well as more stable revenues [111]. This could be confirmed based on the results of this study.

The facilitating conditions not only have a significant positive impact on behavioral intention (0.104), but also on the actual use behavior (0.167) of smart products. It is likely that farmers who have good prerequisites to implement smart products on their farms will be more likely to adopt them. Furthermore, a moderating effect of farm size on facilitating conditions was identified, whereby the facilitating conditions show a stronger effect on the relationship with the intention to use smart products for larger farms of 140 hectares or more. A previous study demonstrated that a favorable farm environment increases the probability that a farmer will adopt technology [112].

A significant influence on behavioral intention could also be demonstrated for the construct of trust. Similar to the facilitating conditions, the influence is rather small (0.104). In a previous study examining the influence of trust on the farmers' intention to use IoT technologies, trust was not found to be a significant factor regarding adoption [57]. However, even though the impact was identified as rather low in the context of this study, trust is crucial for the adoption of smart products, as they have the potential to be complex or poorly conceptualized, which may entail security risks, whether real or perceived [113]. In this study, the statement, "I would follow a recommendation given to me by a smart product" was agreed to somewhat or completely by $53.3 \%$ of the respondents.

The farmers' perception of price value $(0.042)$ and effort expectancy $(-0.057)$ were identified as factors with negligible influence in this study. Studies of precision agriculture report that farmers face adjustments in their operation, transitioning from experiencebased decisions to data-driven processes, leading to uncertainties about the potential costs and benefits of the technology $[17,109]$. In addition, farmers indicate that the costs of smart farming technologies can be unaffordable, and the expectations diverge between experts and farmers regarding the benefits of smart farming technologies $[27,114,115]$. Simultaneously, the demands on the farmers' knowledge and skills have increased due to the growing complexity of technology and management tasks [100]. The farmers' experience with former technology adoptions, in which production increases and labor savings were overestimated, can also contribute to unfulfilled expectations and critical attitudes toward innovative technologies [109]. Furthermore, a moderating effect of work experience on the relationship between price value and behavioral intention was found. For farmers with 10 or less years of work experience, the effect is significantly stronger than for farmers with more than 10 years of work experience.

Last, the hypothesis suggesting that behavioral intention influences actual use behavior could be confirmed $[25,26]$. Behavioral intention thus has a strong influence on whether farmers will actually use smart products. Furthermore, the results demonstrate that the majority of the farmers surveyed are open-minded and interested in the application of smart products.

Conducting an online survey surely poses some limitations. For example, it may limit representativeness because of the differences in internet use among certain segments of the population. Women, older people, and people with little education are less likely to use the internet than men, younger people, and people with higher education [116]. This could be affirmed by the fact that academics are overrepresented in this study. By conducting the survey online, some population groups are reached more easily than others. Persons 
identifying themselves as technology-averse may already be unlikely to participate in an online survey. For this reason, a bias is likely to exist, since the rather positive opinion of the sample could overestimate that of reality. Therefore, online surveys can pose a so-called problem of representativeness. The representativeness can be improved by a parallel application of multiple recruitment methods [117]. With regards to the research question of the present study, the adopted model has a limitation. Due to discriminant validity problems, the construct of habit could not be retained in the model. Habit describes the extent to which respondents learn to perform behaviors automatically. In this case, habit would have signified how quickly and easily smart products could be integrated into the organizational processes of a farm and into a farmer's existing routines. Besides habit, it cannot be denied that the farmers' behavioral intention and use behavior with respect to smart products are influenced by other factors that were not considered in the study's model. Furthermore, farmers who express an intention to use smart products may not realize it in actual use, which is referred to as the intention-behavior gap [118]. Another point of discussion is the strength of the path coefficients and their relevance. The benchmark values for path coefficients are debated in the literature. While some authors consider a value of 0.2 to be acceptable [77], others invoke a value of 0.1 [87]. Thus, it is questionable whether an influence with a path coefficient below 0.1 is worth considering. The constructs of effort expectancy $(-0.057)$ and price value $(0.042)$ have a weak influence and were included in the model in the present study. In spite of the limitations outlined above, the UTAUT model appears to be the appropriate conceptual framework for the study conducted. Hence, more than $60 \%$ of the variance in behavioral intention and $35 \%$ of use behavior could be explained by the determinants embodied in the model.

The question arises as to how smart products can be further disseminated within the framework of smart farming in order to provide a contribution to more sustainable agriculture, and what managerial implications may be derived from the presented results for different stakeholders. These recommended approaches address manufacturers that develop and offer smart technologies, and policymakers in particular. Smart farming manufacturers have a number of opportunities to contribute to the proliferation of smart products. These opportunities relate on the one hand to a specific product itself and on the other hand to their communication with the outside community. Since trust affects the farmers' behavioral intent, compatibility between individual technical systems and the exchange of monitoring data are important aspects, which can be achieved, for example, by establishing internationally applicable legal standards. Since facilitating conditions and performance expectancy have a high influence, companies should prioritize the service they provide and, in the case of farmers, availability in particular. This includes correct installation, necessary maintenance, and support in operating and problem issues. Given that hedonic motivation also has an influence on use behavior, the utilization of a smart product should be associated with a positive experience, which is why products should be designed to be simple and user-friendly in terms of haptics and user interface in order to facilitate uncomplicated use. Furthermore, manufacturers or consulting agencies should clearly communicate the benefits and limitations of smart products to farmers. Ultimately, manufacturers provide the support farmers need, make it easier to learn how to use smart products, and can help reduce uncertainty and complexity. In the context of sustainability, importance should continue to be attached to energy being supplied from renewable sources, such as solar energy. Smart products in agriculture must also be resilient and error-tolerant in order to ensure sustainable operations.

Considering the present results, recommendations can also be provided to policymakers. As facilitating conditions constitute one of the most important determinants for farmers to utilize smart products, the government should provide the necessary assistance for their adoption. This includes the promotion of nationwide broadband coverage, since the majority of agriculture is practiced in rural areas. As farmers' trust is also considered important, policymakers should resolve ambiguities in data security and data sovereignty. Another approach to unite the different stakeholders' interests is to establish a central 
platform for smart farming issues, where farmers can receive advice and possibly training on smart farming and smart products. In addition, they could also express concrete wishes and suggestions for products on such a platform, which in turn could benefit smart farming manufacturers. As agriculture offers diverse farm activities, a central platform can also support the development of individual farm business solutions.

\section{Conclusions}

All in all, the study shows that smart products are perceived rather positively by farmers. This is echoed in the farmers' use patterns, as $65.8 \%$ of respondents reported that they already use smart products on their farm. Among the most impactful determinants of behavioral intention and use behavior, technology readiness and the farmers' hedonic motivation were identified. In addition, social influence, trust, and facilitating conditions further play important roles in the intention to use smart products. Moderating effects of age, work experience, and farm size have been identified as influencing the farmers intention to use smart products.

Since this study identified important determinants of the farmers' behavioral intention and use behavior regarding smart products, it is relevant to investigate how each determinant can be utilized and designed for farmers to ensure farmers' willingness and use behavior not only in Germany but on an international level. Smart farming and smart products have the potential to assist farmers in producing in a more resource-efficient, sustainable, and profitable way that also benefits the environment and the climate. However, the preconditions are that unresolved questions and concerns about data security are eliminated and that farmers can access a central point of contact for smart farming issues.

In future research, farmers could be further segmented according to their farm activities. For example, differences in technology acceptance between livestock farmers and crop farmers might be investigated. This would allow the determinants of behavioral intention to be identified even more precisely in terms of farm activities. This segmentation could help to develop smart products that are even more target-group-specific and adapt them to the wishes and needs of farmers. In addition, research is required to develop new solutions to circumvent the aspects of using smart products that are negatively perceived by farmers, such as the effort involved in learning how to use them or data sovereignty aspects.

Author Contributions: Conceptualization, S.S. and H.H.; methodology, S.S. and H.H.; software, S.S. and H.H.; validation, S.S. and H.H.; formal analysis, S.S. and H.H.; investigation, S.S. and H.H.; data curation, S.S. and H.H.; writing-original draft preparation, S.S. and H.H.; writing-review and editing, S.S. and H.H.; visualization, S.S. and H.H.; supervision, H.H. All authors have read and agreed to the published version of the manuscript.

Funding: This research received no external funding.

Institutional Review Board Statement: Ethical review and approval were waived for this study, due to participation was completely anonymous and all farmers participated on their free will.

Informed Consent Statement: Informed consent was obtained from all subjects involved in the study.

Data Availability Statement: The utilized questionnaire is accessible by contacting the corresponding author.

Acknowledgments: We acknowledge support by the German Research Foundation and the Open Access Publication Funds of the Göttingen University.

Conflicts of Interest: The authors declare no conflict of interest. 


\section{Appendix A}

Table A1. Sample description, $n=523$.

\begin{tabular}{|c|c|c|c|}
\hline Variable & Description & Frequency & Percentage \\
\hline \multirow{2}{*}{$\begin{array}{l}\text { Gender, } \\
n=523\end{array}$} & Male & 403 & 77.1 \\
\hline & Female & 120 & 22.9 \\
\hline \multirow{3}{*}{$\begin{array}{c}\text { Age, } \\
n=523\end{array}$} & Up to 30 years & 141 & 27.0 \\
\hline & 31 to 50 years & 208 & 39.8 \\
\hline & Older than 50 years & 174 & 33.2 \\
\hline \multirow{9}{*}{$\begin{array}{l}\text { Education, } \\
\quad n=523\end{array}$} & No graduation & 1 & 0.2 \\
\hline & Lower secondary education & 2 & 0.4 \\
\hline & Middle school education & 9 & 1.7 \\
\hline & Agricultural education & 26 & 5.0 \\
\hline & Professional school/Meister & 162 & 31.0 \\
\hline & A level & 66 & 12.6 \\
\hline & University degree & 232 & 44.4 \\
\hline & Doctorate or habilitation & 12 & 2.3 \\
\hline & Other & 13 & 2.5 \\
\hline \multirow{7}{*}{$\begin{array}{c}\text { German state, } \\
\quad n=523\end{array}$} & Lower Saxony & 123 & 23.5 \\
\hline & North Rhine-Westphalia & 93 & 17.8 \\
\hline & Bavaria & 71 & 13.6 \\
\hline & Hesse & 39 & 7.5 \\
\hline & Baden-Wuerttemberg & 36 & 6.9 \\
\hline & Saxony-Anhalt & 34 & 6.5 \\
\hline & Other & 127 & 24.2 \\
\hline \multirow{3}{*}{$\begin{array}{l}\text { Work experience, } \\
\qquad n=523\end{array}$} & Up to 10 years & 147 & 28.5 \\
\hline & 11 to 30 years & 227 & 43.4 \\
\hline & More than 30 years & 149 & 28.1 \\
\hline \multirow{2}{*}{$\begin{array}{c}\text { Farm Size, } \\
n=523\end{array}$} & Up to 140 hectares & 274 & 52.4 \\
\hline & More than 140 hectares & 249 & 47.6 \\
\hline
\end{tabular}

\section{Appendix B}

Table A2. Constructs with corresponding items, item loadings, and descriptive analysis with a five-point Likert scale from 1 (totally disagree) to 5 (totally agree), $n=523$ (originally administered in German).

\begin{tabular}{|c|c|c|c|c|}
\hline Construct & Corresponding Item & Loading & Mean & SD \\
\hline \multirow{3}{*}{ Performance Expectancy } & $\begin{array}{l}\text { PE1: Smart products can relieve me of certain work } \\
\text { operations. }\end{array}$ & 0.863 & 4.17 & 0.841 \\
\hline & $\begin{array}{l}\text { PE2: The use of smart products can reduce the } \\
\text { working time for certain activities. }\end{array}$ & 0.843 & 4.06 & 0.886 \\
\hline & $\begin{array}{l}\text { PE3: By using smart products, I save time on } \\
\text { routine tasks on my farm. }\end{array}$ & 0.836 & 3.82 & 0.977 \\
\hline \multirow{4}{*}{ Effort Expectancy } & $\begin{array}{l}\text { EE1: I imagine the handling of smart products to be } \\
\text { difficult. }\end{array}$ & 0.746 & 2.80 & 1.023 \\
\hline & $\begin{array}{l}\text { EE2: Learning how to use smart products is } \\
\text { difficult for me. }\end{array}$ & 0.806 & 2.41 & 1.089 \\
\hline & $\begin{array}{l}\text { EE3: Safe handling of smart products is not easy for } \\
\text { me. }\end{array}$ & 0.634 & 2.63 & 1.163 \\
\hline & $\begin{array}{l}\text { EE4: Using smart products presents a stress factor } \\
\text { for me. }\end{array}$ & 0.818 & 2.46 & 1.083 \\
\hline
\end{tabular}


Table A2. Cont.

\begin{tabular}{|c|c|c|c|c|}
\hline Construct & Corresponding Item & Loading & Mean & SD \\
\hline \multirow{4}{*}{$\begin{array}{l}\text { Social } \\
\text { Influence }\end{array}$} & $\begin{array}{l}\text { SI1: I think it is well appreciated among colleagues } \\
\text { when I use smart products on my farm. }\end{array}$ & 0.740 & 3.28 & 1.012 \\
\hline & $\begin{array}{l}\text { SI2: I think it makes a good impression in society } \\
\text { when I use smart products. }\end{array}$ & 0.751 & 3.31 & 1.017 \\
\hline & $\begin{array}{l}\text { SI3: My social environment (neighbors, colleagues, } \\
\text { friends) approves of smart products on my farm. }\end{array}$ & 0.783 & 3.28 & 1.069 \\
\hline & $\begin{array}{l}\text { SI4: My family is in favor of smart products on my } \\
\text { farm. }\end{array}$ & 0.775 & 3.65 & 1.028 \\
\hline \multirow{2}{*}{ Facilitating Conditions } & $\begin{array}{l}\text { FC1: I meet all the technical requirements for using } \\
\text { smart products in a targeted manner. }\end{array}$ & 0.931 & 3.39 & 1.272 \\
\hline & $\begin{array}{l}\text { FC2: Internet access or mobile internet connection } \\
\text { is available on the whole farm. }\end{array}$ & 0.845 & 3.50 & 1.448 \\
\hline \multirow{2}{*}{ Hedonic Motivation } & $\begin{array}{l}\text { HM1: I want to use smart products when there is } \\
\text { an economic benefit. }\end{array}$ & 0.828 & 4.36 & 0.813 \\
\hline & $\begin{array}{l}\text { HM2: I want to produce more sustainably by } \\
\text { making the best use of resources with the help of } \\
\text { digitization. }\end{array}$ & 0.852 & 4.11 & 0.946 \\
\hline \multirow{3}{*}{$\begin{array}{l}\text { Price } \\
\text { Value }\end{array}$} & $\begin{array}{l}\text { PV1: By using smart products, labor costs can be } \\
\text { reduced. }\end{array}$ & 0.844 & 3.69 & 0.960 \\
\hline & $\begin{array}{l}\text { PV2: By using smart products, I can operate more } \\
\text { efficiently. }\end{array}$ & 0.874 & 3.78 & 0.927 \\
\hline & $\begin{array}{l}\text { PV3: By using smart products, a higher profit can } \\
\text { be generated. }\end{array}$ & 0.832 & 3.29 & 0.923 \\
\hline \multirow{4}{*}{ Trust } & $\begin{array}{l}\text { T1: I trust smart products and the decisions they } \\
\text { make. }\end{array}$ & 0.816 & 3.28 & 0.906 \\
\hline & $\begin{array}{l}\text { T2: I am confident that machines work the way } \\
\text { they are programmed. }\end{array}$ & 0.686 & 3.63 & 0.907 \\
\hline & $\begin{array}{l}\text { T3: I would follow a recommendation that a smart } \\
\text { product gives me. }\end{array}$ & 0.730 & 3.49 & 0.774 \\
\hline & T4: I feel safe working with smart products. & 0.760 & 3.45 & 0.919 \\
\hline \multirow{3}{*}{$\begin{array}{l}\text { Technology } \\
\text { Readiness }\end{array}$} & $\begin{array}{l}\text { TR1: Computers are used on the farm for specific } \\
\text { tasks (e.g., herd management). }\end{array}$ & 0.703 & 4.28 & 1.082 \\
\hline & $\begin{array}{l}\text { TR2: IT systems on my farm make decisions on } \\
\text { their own. }\end{array}$ & 0.667 & 2.27 & 1.184 \\
\hline & TR3: Various sensors are used on my farm. & 0.843 & 3.42 & 1.308 \\
\hline \multirow{3}{*}{$\begin{array}{l}\text { Behavioral } \\
\text { Intention }\end{array}$} & $\begin{array}{l}\text { BI1: I would use smart products on my farm } \\
\text { immediately. }\end{array}$ & 0.821 & 3.57 & 1.018 \\
\hline & $\begin{array}{l}\text { BI2: I plan to use smart products on my farm in the } \\
\text { future. }\end{array}$ & 0.901 & 3.63 & 1.116 \\
\hline & $\begin{array}{l}\text { BI3: I intend to use smart products on my farm in } \\
\text { the near future. }\end{array}$ & 0.893 & 3.56 & 1.147 \\
\hline $\begin{array}{c}\text { Use } \\
\text { Behavior * }\end{array}$ & $\begin{array}{l}\text { UB1: Smart phone for monitoring or controlling } \\
\text { operating units such as machines or barn } \\
\text { equipment, as well as fulfilling documentation } \\
\text { obligations or recruiting personnel (operational } \\
\text { purposes other than telephoning or other } \\
\text { communication) }\end{array}$ & 1.000 & 3.45 & 1.422 \\
\hline
\end{tabular}

\footnotetext{
* Use behavior was measured by frequency of use using a five-point scale from 1 (never) to 5 (several times a day), $n=523$.
} 


\section{Appendix C}

Table A3. Internal consistency: Cronbach's alpha, composite reliability, and AVE of the constructs.

\begin{tabular}{cccc}
\hline Construct & $\begin{array}{c}\text { Cronbach's } \\
\text { Alpha }\end{array}$ & Composite Reliability & Average Variance Extracted \\
\hline Performance Expectancy & 0.804 & 0.884 & 0.718 \\
Effort Expectancy & 0.751 & 0.840 & 0.569 \\
Social Influence & 0.765 & 0.847 & 0.581 \\
Facilitating Conditions & 0.742 & 0.882 & 0.790 \\
Hedonic Motivation & 0.583 & 0.827 & 0.706 \\
Price Value & 0.809 & 0.887 & 0.723 \\
Trust & 0.739 & 0.836 & 0.562 \\
Technology Readiness & 0.587 & 0.784 & 0.550 \\
Behavioral Intention & 0.842 & 0.905 & 0.761 \\
Use Behavior & 1.000 & 1.000 & 1.000 \\
\hline
\end{tabular}

\section{Appendix D}

Table A4. Discriminant validity: HTMT.

\begin{tabular}{|c|c|c|c|c|c|c|c|c|c|c|}
\hline Construct & BI & $\mathrm{EE}$ & FC & HM & PE & PV & SI & TR & $\mathbf{T}$ & UB \\
\hline \multicolumn{11}{|l|}{ BI } \\
\hline $\mathrm{EE}$ & 0.429 & & & & & & & & & \\
\hline $\mathrm{FC}$ & 0.502 & 0.304 & & & & & & & & \\
\hline $\mathrm{HM}$ & 0.865 & 0.446 & 0.384 & & & & & & & \\
\hline $\mathrm{PE}$ & 0.727 & 0.439 & 0.332 & 0.882 & & & & & & \\
\hline PV & 0.731 & 0.376 & 0.375 & 0.845 & 0.898 & & & & & \\
\hline SI & 0.715 & 0.345 & 0.396 & 0.736 & 0.621 & 0.735 & & & & \\
\hline TR & 0.840 & 0.269 & 0.525 & 0.677 & 0.547 & 0.620 & 0.574 & & & \\
\hline $\mathrm{T}$ & 0.788 & 0.495 & 0.436 & 0.827 & 0.795 & 0.835 & 0.748 & 0.729 & & \\
\hline UB & 0.550 & 0.209 & 0.426 & 0.408 & 0.340 & 0.307 & 0.335 & 0.679 & 0.439 & \\
\hline
\end{tabular}

BI: Behavioral Intention; EE: Effort Expectancy; FC: Facilitating Conditions; HM: Hedonic Motivation; PE: Performance Expectancy; PV: Price Value; SI: Social Influence; TR: Technology Readiness; T: Trust; UB: Use Behavior.

\section{Appendix E}

Table A5. MGA results: moderating effects of gender and farm size.

\begin{tabular}{|c|c|c|c|c|c|c|}
\hline \multicolumn{4}{|c|}{ Path Coefficients Gender } & \multicolumn{3}{|c|}{ Path Coefficients Farm Size } \\
\hline Path & Male & Female & Difference & $\begin{array}{l}\text { Up to } 140 \\
\text { Hectares }\end{array}$ & $\begin{array}{c}\text { More than } 140 \\
\text { Hectares }\end{array}$ & Difference \\
\hline $\mathrm{BI} \rightarrow \mathrm{UB}$ & 0.285 & 0.149 & 0.135 & 0.246 & 0.219 & 0.027 \\
\hline $\mathrm{EE} \rightarrow \mathrm{BI}$ & -0.080 & -0.076 & -0.004 & -0.056 & -0.092 & 0.036 \\
\hline $\mathrm{FC} \rightarrow \mathrm{BI}$ & 0.098 & 0.109 & -0.011 & 0.042 & 0.194 & $-0.152 *$ \\
\hline $\mathrm{FC} \rightarrow \mathrm{UB}$ & 0.160 & 0.173 & -0.013 & 0.202 & 0.148 & 0.054 \\
\hline $\mathrm{HM} \rightarrow \mathrm{BI}$ & 0.202 & 0.144 & 0.058 & 0.161 & 0.225 & -0.064 \\
\hline $\mathrm{PE} \rightarrow \mathrm{BI}$ & 0.143 & 0.224 & -0.081 & 0.186 & 0.184 & 0.002 \\
\hline $\mathrm{PV} \rightarrow \mathrm{BI}$ & 0.042 & 0.023 & 0.019 & 0.014 & 0.054 & -0.04 \\
\hline $\mathrm{SI} \rightarrow \mathrm{BI}$ & 0.157 & 0.248 & -0.091 & 0.150 & 0.191 & -0.041 \\
\hline $\mathrm{TR} \rightarrow \mathrm{BI}$ & 0.269 & 0.234 & 0.036 & 0.324 & 0.178 & 0.146 * \\
\hline $\mathrm{TR} \rightarrow \mathrm{UB}$ & 0.270 & 0.416 & -0.146 & 0.344 & 0.220 & 0.124 \\
\hline $\mathbf{T} \rightarrow \mathbf{B I}$ & 0.113 & 0.066 & 0.047 & 0.146 & 0.038 & 0.108 \\
\hline
\end{tabular}

Significance level: $* x \leq 0.05$. BI: Behavioral Intention; EE: Effort Expectancy; FC: Facilitating Conditions; HM: Hedonic Motivation; PE: Performance Expectancy; PV: Price Value; SI: Social Influence; TR: Technology Readiness; T: Trust; UB: Use Behavior. 


\section{Appendix F}

Table A6. MGA results: moderating effects of age.

\begin{tabular}{|c|c|c|c|c|c|c|}
\hline \multicolumn{7}{|c|}{ Path Coefficients Age } \\
\hline Path & $\begin{array}{c}\text { Up to } 30 \text { Years } \\
\text { (1) }\end{array}$ & $\begin{array}{c}31 \text { to } 50 \text { Years } \\
\text { (2) }\end{array}$ & $\begin{array}{c}\text { More than } 50 \\
\text { Years (3) }\end{array}$ & $\begin{array}{l}\text { Difference } \\
\text { (1)—(2) }\end{array}$ & $\begin{array}{l}\text { Difference } \\
\text { (1)—(3) }\end{array}$ & $\begin{array}{c}\text { Difference } \\
\text { (2)-(3) }\end{array}$ \\
\hline $\mathrm{BI} \rightarrow \mathrm{UB}$ & 0.246 & 0.272 & 0.227 & -0.025 & 0.019 & 0.044 \\
\hline $\mathrm{EE} \rightarrow \mathrm{BI}$ & -0.110 & -0.036 & -0.076 & -0.074 & -0.034 & 0.040 \\
\hline $\mathrm{FC} \rightarrow \mathrm{BI}$ & 0.086 & 0.042 & 0.170 & 0.044 & -0.083 & -0.127 \\
\hline $\mathrm{FC} \rightarrow \mathrm{UB}$ & 0.154 & 0.137 & 0.183 & 0.018 & -0.029 & -0.047 \\
\hline $\mathrm{HM} \rightarrow \mathrm{BI}$ & 0.140 & 0.221 & 0.189 & -0.081 & -0.049 & 0.031 \\
\hline $\mathrm{PE} \rightarrow \mathrm{BI}$ & 0.068 & 0.242 & 0.164 & -0.173 & -0.096 & 0.077 \\
\hline $\mathrm{PV} \rightarrow \mathrm{BI}$ & -0.005 & 0.012 & 0.147 & -0.017 & -0.152 & -0.135 \\
\hline $\mathrm{SI} \rightarrow \mathrm{BI}$ & 0.269 & 0.141 & 0.144 & 0.127 & 0.125 & -0.002 \\
\hline $\mathrm{TR} \rightarrow \mathrm{BI}$ & 0.433 & 0.170 & 0.210 & $0.264 * *$ & $0.223 * *$ & -0.041 \\
\hline $\mathrm{TR} \rightarrow \mathrm{UB}$ & 0.310 & 0.300 & 0.354 & 0.009 & -0.045 & -0.054 \\
\hline $\mathbf{T} \rightarrow \mathbf{B I}$ & 0.088 & 0.198 & 0.018 & -0.110 & 0.070 & 0.180 \\
\hline
\end{tabular}

Significance level: ${ }^{* *} p \leq 0.01$. BI: Behavioral Intention; EE: Effort Expectancy; FC: Facilitating Conditions; HM: Hedonic Motivation; PE: Performance Expectancy; PV: Price Value; SI: Social Influence; TR: Technology Readiness; T: Trust; UB: Use Behavior.

\section{Appendix G}

Table A7. MGA results: moderating effects of work experience.

\begin{tabular}{|c|c|c|c|c|c|c|}
\hline \multicolumn{7}{|c|}{ Path Coefficients Work Experience } \\
\hline Path & $\begin{array}{l}\text { Up to } 10 \text { Years } \\
\text { (4) }\end{array}$ & $\begin{array}{c}11 \text { to } 30 \text { Years } \\
\text { (5) }\end{array}$ & $\begin{array}{c}\text { More than } 30 \\
\text { Years (6) }\end{array}$ & $\begin{array}{l}\text { Difference } \\
\text { (4)-(5) }\end{array}$ & $\begin{array}{l}\text { Difference } \\
\text { (4)-(6) }\end{array}$ & $\begin{array}{c}\text { Difference } \\
(5)-(6)\end{array}$ \\
\hline $\mathrm{BI} \rightarrow \mathrm{UB}$ & 0.249 & 0.292 & 0.205 & -0.043 & 0.045 & 0.088 \\
\hline $\mathrm{EE} \rightarrow \mathrm{BI}$ & -0.102 & -0.060 & -0.072 & -0.042 & -0.030 & 0.012 \\
\hline $\mathrm{FC} \rightarrow \mathrm{BI}$ & 0.036 & 0.110 & 0.102 & -0.074 & -0.065 & 0.008 \\
\hline $\mathrm{FC} \rightarrow \mathrm{UB}$ & 0.144 & 0.110 & 0.247 & 0.034 & -0.103 & -0.138 \\
\hline $\mathrm{HM} \rightarrow \mathrm{BI}$ & 0.179 & 0.158 & 0.274 & 0.020 & -0.096 & -0.116 \\
\hline $\mathrm{PE} \rightarrow \mathrm{BI}$ & 0.062 & 0.274 & 0.106 & -0.212 & -0.044 & 0.168 \\
\hline $\mathrm{PV} \rightarrow \mathrm{BI}$ & 0.006 & -0.040 & 0.233 & 0.046 & $-0.226 *$ & $-0.273 * *$ \\
\hline $\mathrm{SI} \rightarrow \mathrm{BI}$ & 0.250 & 0.173 & 0.136 & 0.078 & 0.114 & 0.036 \\
\hline $\mathrm{TR} \rightarrow \mathrm{BI}$ & 0.412 & 0.233 & 0.131 & $0.179 * *$ & $0.281 * *$ & 0.101 \\
\hline $\mathrm{TR} \rightarrow \mathrm{UB}$ & 0.293 & 0.333 & 0.309 & -0.040 & -0.015 & 0.025 \\
\hline $\mathbf{T} \rightarrow \mathrm{BI}$ & 0.079 & 0.142 & 0.023 & -0.062 & 0.056 & 0.119 \\
\hline
\end{tabular}

Significance level: ${ }^{*} p \leq 0.05,{ }^{* *} p \leq 0.01$. BI: Behavioral Intention; EE: Effort Expectancy; FC: Facilitating Conditions; HM: Hedonic Motivation; PE: Performance Expectancy; PV: Price Value; SI: Social Influence; TR: Technology Readiness; T: Trust; UB: Use Behavior.

\section{References}

1. Porter, J.R.; Xie, L.; Challinor, A.J.; Cochrane, K.; Howden, S.M. Chapter 7: Food Security and Food Production Systems; Cambridge University Press: Cambridge, UK, 2014. [CrossRef]

2. Prasanna, V. Impact of monsoon rainfall on the total foodgrain yield over India. J. Earth Syst. Sci. 2014, 123, 1129-1145. [CrossRef]

3. Brida, A.B.; Owiyo, T. Loss and damage from the double blow of flood and drought in Mozambique. Int. J. Glob. Warm. 2013, 5, 214-531. [CrossRef]

4. Teschner, N.A.M.; Orenstein, D.E.; Shapira, I.; Kasesar, T. Socio-ecological research and the transition toward sustainable agriculture. Int. J. Agirc. Sustain. 2017, 15, 99-101. [CrossRef]

5. Rockström, J.; Williams, J.; Daily, G.; Noble, A.; Matthews, N.; Gordon, L.; Wetterstrand, H.; DeClerck, F.; Shah, M.; Steduto, P. Sustainable intensification of agriculture for human prosperity and global sustainability. Ambio 2017, 46, 4-17. [CrossRef] [PubMed]

6. Walter, A.; Finger, R.; Huber, R.; Buchmann, N. Smart farming is key to developing sustainable agriculture. Proc. Natl. Acad. Sci. USA 2017, 114, 6148-6150. [CrossRef] [PubMed]

7. Aubert, B.A.; Schroeder, A.; Grimaudo, J. IT as enabler of sustainable farming: An empirical analysis of farmers' adoption decision of precision agriculture technology. Dec. Supp. Syst. 2012, 54, 510-520. [CrossRef] 
8. Li, F.; Mistele, B.; Hu, Y.; Chen, X.; Schmidhalter, U. Reflectance estimation of canopy nitrogen content in winter wheat using optimized hyperspectral indices and partial least squares regression. Eur. J. Agron. 2014, 52, 198-209. [CrossRef]

9. Umstatter, C. The evolution of virtual fences. A review. Comput. Electron. Agric. 2011, 75, 10-22. [CrossRef]

10. Porter, M.E.; Heppelmann, J.E. How smart, connected products are transforming competition. Harv. Bus. Rev. 2014, 92, 65-88.

11. Fleisch, E.; Thiesse, F. On the Management Implications of Ubiquitous Computing: An IS Perspective. In Proceedings of the European Conference on Information Systems (ECIS), St. Gallen, Switzerland, 7-9 June 2007.

12. Mayer, P.; Volland, D.; Thiesse, F.; Fleisch, R. User Acceptance of Smart Products: An Empirical Investigation. In Wirtschaftsinformatik Proceedings 2011; Lulu: Zurich, Switzerland, 2011.

13. Wolfert, S.; Ge, L.; Verdouw, C.; Bogaardt, M.J. Big Data in Smart Farming-A Review. Agric. Syst. 2017, 153, 69-80. [CrossRef]

14. Schulze, E.D.; Luyssaert, S.; Ciais, P.; Freibauer, A.; Janssens, I.A.; Soussana, J.F.; Smith, P.; Grace, J.; Levin, I.; Thiruchittampalam, B.; et al. Importance of methane and nitrous oxide for Europe's terrestrial greenhouse-gas balance. Nat. Geosci. 2009, 2, 842-850. [CrossRef]

15. DeFries, R.; Fanzo, J.; Remans, R.; Palm, C.; Wood, S.; Anderman, T.L. Global nutrition. Metrics for land-scarce agriculture. Science 2015, 349, 238-240. [CrossRef]

16. Charo, R.A. Science and Government. Yellow lights for emerging technologies. Science 2015, 349, 384-385. [CrossRef]

17. Kutter, T.; Tiemann, S.; Siebert, R.; Fountas, S. The role of communication and co-operation in the adoption of precision farming. Precis. Agric. 2011, 12, 2-17. [CrossRef]

18. Already 8 Out of 10 Farmers Rely on Digital Technologies. Available online: https://www.bitkom.org/Presse/Presseinformation/ Schon-8-von-10-Landwirten-setzen-auf-digitale-Technologien (accessed on 6 May 2021).

19. Digitization in Agriculture. Exploiting Opportunities-Minimizing Risks. Available online: https://www.bmel.de/SharedDocs/ Downloads/DE/Broschueren/digitalpolitik-landwirtschaft.pdf?_blob=publicationFile\&v=16 (accessed on 6 May 2021).

20. McBride, W.D.; Daberkow, S.G. Information and the adoption of precision farming technologies. J. Agribus. 2003, 21, 31-38. [CrossRef]

21. Daberkow, S.G.; McBride, W.D. Farm and operator characteristics affecting the awareness and adoption of precision agriculture technologies in the US. Precis. Agric. 2003, 4, 163-177. [CrossRef]

22. Kitchen, N.R.; Snyder, C.J.; Franzen, D.W.; Wiebold, W.J. Educational needs of precision agriculture. Precis. Agric. 2002, 3, 341-351. [CrossRef]

23. Ronaghi, M.H.; Forouharfar, A. A contextualized study of the usage of the Internet of things (IoTs) in smart farming in a typical Middle Eastern country within the context of Unified Theoriy of Acceptance and Use of Technology model (UTAUT). Technol. Soc. 2020, 63, 101415. [CrossRef]

24. Michels, M.; Fecke, W.; Feil, J.H.; Mußhoff, O.; Pigisch, J.; Krone, S. Smartphone adoption and use in agriculture: Empirical evidence from Germany. Precis. Agric. 2020, 21, 403-425. [CrossRef]

25. Venkatesh, V.; Thong, J.Y.; Xu, X. Consumer acceptance and use of information technology: Extending the unified theory of acceptance and use of technology. MIS Q. 2012, 1, 157-178. [CrossRef]

26. Venkatesh, V.; Morris, M.G.; Davis, G.B.; Davis, F.D. User Acceptance of Information Technology: Toward a Unified View. MIS Q. 2003, 27, 425-478. [CrossRef]

27. Kernecker, M.; Knierim, A.; Wurbs, A.; Kraus, T.; Borges, F. Experience versus expectation: Farmers' perceptions of smart farming technologies for cropping systems across Europe. Precis. Agric. 2020, 21, 34-50. [CrossRef]

28. Yeates, J.W. How good? Ethical criteria for a 'Good Life' for farm animals. J. Agric. Environ. Ethics 2017, 30, 23-35. [CrossRef]

29. Sheng, Y.; Davidson, A.; Fuglie, K.; Zhang, D. Input Substitution, Productivity Performance and Farm Size. Aust. J. Agric. Econ. 2016, 60, 327-347. [CrossRef]

30. Rose, D.C.; Sutherland, W.J.; Parker, C.; Lobley, M.; Winter, M.; Morris, C.; Twining, S.; Foulkes, C.; Amano, T.; Dicks, L.V. Decision support tools for agriculture: Towards effective design and delivery. Agric. Syst. 2016, 149, 165-174. [CrossRef]

31. Abdullah, F.A.; Samah, B.A. Factors Impinging Farmers' Use of Agriculture Technology. Asian Soc. Sci. 2013, 9, 120-124. [CrossRef]

32. Sabuhoro, J.B.; Wunsch, P. Computer Technology Adoption by Canadian Farm Businesses: An Analysis Based on the 2001 Census of Agriculture; Citeseer: Philadelphia, PA, USA, 2003; pp. 1-14. [CrossRef]

33. Perrin, R.; Winkelmann, D. Impediments to Technical Progress on Small versus Large Farms. Am. J. Agric. Econ. 1976, 58, 888. [CrossRef]

34. Kuczera, C. The Influence of the Social Environment on Farm Decisions of Farmers; Margraf Publishers: Weikersheim, Germany, 2006; pp. 56-171. (In German)

35. Foster, A.D.; Rosenzweig, M.R. Learning by Doing and Learning from Others: Human Capital and Technical Change in Agriculture. J. Polit. Econ. 1995, 103, 1176-1209. [CrossRef]

36. Bahner, T. Agricultural company design according to personal goals. Agrarwirtschaft 1995, 44, 343-349. (In German)

37. Hall, D.; Mansfield, R. Relationships of age and seniority with career variables of engineers and scientists. J. Appl. Psychol. 1975, 60, 201-210. [CrossRef]

38. Minton, H.L.; Schneider, F.W. Differential Psychology; Waveland Press Inc.: Long Grove, IL, USA, 1984.

39. Warshaw, P.R. A New Model for Predicting Behavioral Intentions: An Alternative to Fishbein. J. Mark. Res. 1980, 17, 153-172. [CrossRef] 
40. Kloch, C.; Petersen, E.B.; Madsen, O.B. Cloud based infrastructure, the new business possibilities and barriers. Wirel. Pers. Commun. 2011, 58, 17-30. [CrossRef]

41. Leitão, P.; Colombo, A.W.; Karnouskos, S. Industrial automation based on cyber-physical system technologies; Prototype implementations and challenges. Comp. Ind. 2016, 3, 11-25. [CrossRef]

42. Aboelmaged, M.G. An empirical analysis of ERP implementation in a developing country: Toward a generic framework. Int. J. Netw. Manag. 2009, 3, 309-331. [CrossRef]

43. Oliveira, T.; Thomas, M.; Espadanal, M. Assessing the determinants of cloud computing adoption: An analysis of the manufacturing and service sectors. Inf. Manag. 2014, 51, 497-510. [CrossRef]

44. Venkatesh, V.; Morris, M. Why don't men ever stop asking for directions? Gender, social influence, and their role in technology acceptance and usage behavior. MIS Q. 2000, 24, 115-140. [CrossRef]

45. Just, R.E.; Zilberman, D. Stochastic Structure, Farm Size and Technology Adoption in Developing Agriculture. Ox. Econ. Pap. 1983, 35, 307-328. [CrossRef]

46. Zhang, N.; Wang, M.; Wang, N. Precision agriculture-A worldwide overview. Comput. Electron. Agric. 2002, 36, 113-132. [CrossRef]

47. Uematsu, H.; Mishra, A.K. Use of Direct Marketing Strategies by Farmers and Their Impact on Farm Business Income. Agric. Resour. Econ. 2011, 40, 1-19. [CrossRef]

48. Chau, P.Y.; Hui, K.L. Identifying Early Adopters of New IT Products: A Case of Windows 95. Inf. Manag. 1998, 33, 225-230. [CrossRef]

49. Eastwood, C.R.; Kenny, S. Art or science? Heuristic versus data driven grazing management on dairy farms. Ext. Farming Syst. J. 2009, 5, 95-102. [CrossRef]

50. Nuthall, P.L. The intuitive world of farmers-The case of grazing management systems and experts. Agric. Syst. 2012, 107, 65-73. [CrossRef]

51. Deaux, K.; Lewis, L.L. Structure of Gender Stereotypes: Interrelationships among Components and Gender label. J. Pers. Soc. Psych. 1984, 28, 991-1004. [CrossRef]

52. Limayem, M.; Hirt, S.G.; Cheung, C.M.K. How Habit Limits the Predictive Power of Intentions: The Case of IS Continuance. MIS Q. 2007, 31, 705-737. [CrossRef]

53. Darley, W.K.; Smith, R.E. Gender Differences in Information Processing Strategies: An Empirical Test of the Selectivity Model in Advertising Response. J. Advert. 1995, 24, 41-56. [CrossRef]

54. Feder, G. Farm Size, Risk Aversion and the Adoption of New Technology under Uncertainty. Ox. Econ. Pap. 1980, 32, 263-283. [CrossRef]

55. Devitt, S.K. Cognitive factors that affect the adoption of autonomous agriculture. Farm Policy J. 2018, 15, 49-60.

56. McAllister, D.J. Affect- and Cognition-based Trust as Foundations for Interpersonal Cooperation in Organizations. Acad. Manag. J. 1995, 38, 24-59. [CrossRef]

57. Duang-Ek-Anong, S.; Pibulcharoensit, S.; Phongsatha, T. Technology Readiness for Internet of Things (IoT) Adoption in Smart Farming in Thailand. Int. J. Simul. Syst. Sci. Technol. 2019, 20, 1-6. [CrossRef]

58. Eidt, C.M.; Hickey, G.M.; Curtis, M.A. Knowledge integration and the adoption of new agricultural technologies: Kenyan perspectives. Food Secur. 2012, 4, 355-367. [CrossRef]

59. Snyder, C.R. Handbook of Hope; Academic Press: San Diego, CA, USA, 2000.

60. Bukchin, S.; Kerret, D. Food for Hope: The Role of Personal Resources in Farmers' Adoption of Green Technology. Sustainability 2018, 10, 1615. [CrossRef]

61. Krampen, G.; Viebig, J.; Walter, W. Developing a scale to capture three aspects of social trust. Diagnostica 1982, 3, 242-247. (In German)

62. Ho, S.M.; Ocasio-Velázquez, M.; Booth, C. Trust or consequences? Causal effects of perceived risk and subjective norms on cloud technology adoption. Comput. Secur. 2017, 70, 581-959. [CrossRef]

63. Jia, X.; James, H.S. Organizational trust in farmer organizations: Evidence from the Chinese fresh apple industry. Br. Food J. 2018, 120, 676-689. [CrossRef]

64. Neyer, F.J.; Felber, J.; Gebhardt, C. Development and validation of a short scale for recording technology readiness (technology commitment). Diagnostica 2012, 58, 87-99. (In German) [CrossRef]

65. Haug, A.; Pederson, S.G.; Arlbjørn, J.S. IT readiness in small and medium-sized enterprises. Ind. Manag. Data Syst. 2011, 29, 490-508. [CrossRef]

66. Chen, S.; Chen, H.; Chen, M. Determinants of satisfaction and continuance intention towards self-service technologies. Ind. Manag. Data Syst. 2009, 109, 1249-1263. [CrossRef]

67. Shih, C.L.H.; Sher, P.J. Integrating technology readiness into technology acceptance: The TRAM model. Psychol. Mark. 2007, 24, 641-645. [CrossRef]

68. Mwangi, M.; Kariuki, S. Factors Determining Adoption of New Agricultural Technology by Smallholder Farmers in Developing Countries. J. Econ. Sustain. Dev. 2015, 6, 208-216.

69. Arning, K.; Ziefle, M. Understanding age differences in PDA acceptance and performance. Comput. Hum. Behav. 2007, 23, 2904-2927. [CrossRef] 
70. Blut, M.; Wang, C. Technology readiness: A meta-analysis of conceptualizations of the construct and its impact on technology usage. J. Acad. Mark. Sci. 2020, 48, 649-669. [CrossRef]

71. Sheppard, B.H.; Hartwick, J.; Warshaw, P.R. The Theory of Reasoned Action: A Meta-Analysis of Past Research with Recommendations for Modifications and Future Research. J. Consum. Res. 1988, 15, 325-343. [CrossRef]

72. Tripathi, S. Moderating effects of age and experience on the factors influencing the actual usage of cloud computing. J. Inf. Technol. Manag. 2018, 27, 6.

73. Heiman, A.; Ferguson, J.; Zilberman, D. Marketing and Technology Adoption and Diffusion. Appl. Econ. Perspect. Policy 2020, 42, 21-30. [CrossRef]

74. Homburg, C.; Gierung, A. Conceptualization and operationalization of complex constructs. A Guide to Marketing Research. Market. ZFP 1996, 18, 5-24. (In German)

75. Henseler, J.; Chin, W.W. A Comparison of Approaches for the Analysis of Interaction Effects Between Latent Variables Using Partial Least Squares Path Modeling. Struct. Equ. Model. 2010, 17, 82-109. [CrossRef]

76. Ringle, C.M.; Wende, S.; Becker, J.-M. 2015 “SmartPLS 3" Boenningstedt: SmartPLS GmbH. Available online: http://www. smartpls.com (accessed on 15 December 2020).

77. Chin, W.W. Commentary: Issues and Opinion on Structural Equation Modeling. MIS Q. 1998, 22, vii-xvi.

78. Cronbach, L.J. Coefficient alpha and the internal structure of tests. Psychometrika 1951, 16, 297-334. [CrossRef]

79. Schmitt, N. Uses and abuses of coefficient alpha. Psychol. Assess. 1996, 8, 350-353. [CrossRef]

80. Hair, J.F.; Hult, G.T.M.; Ringle, C.; Sarstedt, M. A Primer on Partial Least Squares Structural Equation Modeling (PLS-SEM), 2nd ed.; Sage Publications: Newbury Park, CA, USA, 2016.

81. Chin, W.W. The partial least squares approach to structural equation modeling. Mod. Methods Bus. Res. 1998, 295, 295-336.

82. Bagozzi, R.P.; Yi, Y. On the evaluation of structural equation models. J. Acad. Mark. Sci. 1988, 16, 74-94. [CrossRef]

83. Fornell, C.; Larcker, D.F. Evaluating Structural Equation Models with Unobservable Variables and Measurement Error. J. Mark. Res. 1981, 18, 39-50. [CrossRef]

84. Henseler, J.; Ringle, C.M.; Sarstedt, M. A new criterion for assessing discriminant validity in variance-based structural equation modeling. J. Acad. Mark. Sci. 2015, 43, 115-135. [CrossRef]

85. Götz, O.; Liehr-Gobbers, K.; Krafft, M. Evaluation of Structural Equation Models Using the Partial Least Squares (PLS) Approach. In Handbook of Partial Least Squares: Concepts, Methods and Applications. Springer Handbooks of Computational Statistics; Esposito Vinzi, V., Chin, W.W., Henseler, J., Wang, H., Eds.; Springer: Berlin/Heidelberg, Germany, 2010; pp. 691-711.

86. Efron, B.; Tibshirani, R.J. An Introduction to the Bootstrap; CRC Press: Jacksonville, FL, USA, 1994.

87. Lohmöller, J.B. The PLS program system: Latent variables path analysis with partial least squares estimation. Multivar. Behav. Res. 1988, 23, 125-127. [CrossRef] [PubMed]

88. Götz, O.; Liehr-Gobbers, K. Analysis of structural equation models using the partial least squares (PLS) method. Die Betr. 2004, 64,714-738. (In German)

89. SmartPLS Guide. Evaluation of Structural Equation Models. Available online: http:/ / www.marketing-i.bwl.unimainz.de/660. Php (accessed on 27 January 2021). (In German).

90. Cohen, J. Statistical Power Analysis for the Behavioral Sciences, 2nd ed.; Lawrence Erlbaum: Mahwah, NJ, USA, 1988.

91. Stone, M. Cross-validatory choice and assessment of statistical predictions. J. R. Stat. Soc. Ser. B Methodol. 1974, 36, 111-147. [CrossRef]

92. Geisser, S. A predictive approach to the random effect model. Biometrika 1974, 61, 101-107. [CrossRef]

93. Baron, R.M.; Kenny, D.A. The moderator-mediator variable distinction in social psychological research: Conceptual, strategic, and statistical considerations. J. Pers. Soc. Psychol. 1986, 51, 1173. [CrossRef]

94. Ringle, C.M.; Sinkovics, R.R.; Henseler, J. The use of partial least squares path modeling in international marketing. In New Challenges to International Marketing; Emerald Group Publishing: Bingley, UK, 2009; pp. 277-319.

95. Situation Report 2016/17: Employees, Trainees and Successors. Available online: https://www.bauernverband.de/35 -arbeitskraefte-auszubildende-und-hofnachfolger-683386 (accessed on 22 January 2021). (In German).

96. Statistical Offices of the Federation and the Federal States. Agricultural Structures in Germany. Unity in Diversity; Statistical Offices of the Federation and the Federal States: Wiesbaden, Germany, 2010; pp. 31-33. (In German)

97. German Farmers' Association. Situation Report 2020/21. Trends and Facts about Agriculture; DBV: Berlin, Germany, 2020. (In German)

98. Weltzien, C. Digital agriculture-Or why agriculture 4.0 still offers only modest returns. Agric. Eng. 2016, 7, 66-68. [CrossRef]

99. Miranda, J.; Ponce, P.; Molina, A.; Wright, P. Sensing, smart and sustainable technology for Agri-Food 4.0. Comp. Ind. 2019, 108, 21-36. [CrossRef]

100. Busse, M.; Schwerdtner, W.; Siebert, R.; Doernberg, A.; Kuntosch, A.; König, B.; Bokelmann, W. Analysis of animal monitoring technologies in Germany from an innovation system perspective. Agric. Syst. 2015, 138, 55-65. [CrossRef]

101. Feder, G.; Umali, D.L. The adoption of agricultural innovations: A review. Technol. Forecast. Soc. Chang. 1993, 43, 215-239. [CrossRef]

102. Feder, G.; Just, R.E.; Zilberman, D. Adoption of agricultural innovations in developing countries: A survey. Dev. Cult. Chang. 1985, 33, 255-298. [CrossRef] 
103. Cavallo, E.; Ferrari, E.; Bollani, L.; Coccia, M. Attitudes and behavior of adopters of technological innovations in agricultural tractors: A case study in Italian agricultural system. Agric. Syst. 2014, 130, 44-54. [CrossRef]

104. Ramus, C.A.; Steger, U. The Roles of Supervisory Support Behaviors and Environmental Policy in Employee 'Ecoinitiatives' at Leading-Edge European Companies. Acad. Manag. J. 2000, 43, 605-626. [CrossRef]

105. Tamirat, T.W.; Pedersen, S.M.; Lind, K.M. Farm operator characteristics affecting adoption of precision agriculture in Denmark and Germany. Acta Agric. Scand. Sect. B 2018, 68, 349-357. [CrossRef]

106. Tiffin, R.; Balcombe, K. The determinants of technology adoption by UK farmers using Bayesian model averaging: The cases of organic production and computer usage. Aust. J. Agric. Econ. 2011, 55, 579-598. [CrossRef]

107. Kling-Eveillard, F.; Dockes, A.C.; Souquet, C. Attitudes of French pig farmers towards animal welfare. Br. Food J. 2007, 109, 859-869. [CrossRef]

108. Eastwood, C.R.; Chapman, D.F.; Paine, M.S. Networks of practice for co-construction of agricultural decision support systems: Case studies of precision dairy farms in Australia. Agric. Syst. 2012, 108, 10-18. [CrossRef]

109. Eastwood, C.; Klerkx, L.; Nettle, R. Dynamics and distribution of public and private research and extension roles for technological innovation and diffusion: Case studies of the implementation and adoption of precision farming technologies. J. Rural. Stud. 2017, 49, 1-12. [CrossRef]

110. Leeuwis, C.; van den Ban, A.W. Communication for Rural Innovation: Rethinking Agricultural Extension; Blackwell Science: Oxford, UK, 2003.

111. Mariano, M.J.; Villano, R.; Fleming, E. Factors influencing farmers' adoption of modern rice technologies and good management practices in the Philippines. Agric. Syst. 2012, 110, 41-53. [CrossRef]

112. Green, G. Explaining irrigation technology choices: A microparameter approach. Am. J. Agric. Econ. 1996, 78, 1064-1072. [CrossRef]

113. Sicari, S.; Rizzardi, A.; Grieco, L.A.; Coen-Porisini, A. Security, privacy and trust in Internet of Things: The road ahead. Comp. Netw. 2015, 76, 146-164. [CrossRef]

114. Barnes, A.; De Soto, I.; Eory, B.; Balafoutis, A.; Sánchez, B.; Vangeyte, J.; Fountas, S.; van der Wal, T.; Gómez-Barbero, M. Influencing factors and incentives on the intention to adopt precision agricultural technologies within arable farming systems. Environ. Sci. Policy 2019, 93, 66-74. [CrossRef]

115. Klerkx, L.; Rose, D. Dealing with the game-changing technologies of Agriculture 4.0: How do we manage diversity and responsibility in food system transition pathways? Glob. Food Sec. 2020, 24, 100347. [CrossRef]

116. Büchi, M.; Just, N.; Latzer, M. Internet Use in Comparison: Socio-Demographic Differences in Five Countries. New Media Soc. 2015, 18, 2703-2722. [CrossRef]

117. Bauer, H.H.; Wölfer, H. Possibilities and Limits of Online Market Research; Institute for Market-Oriented Management, University of Mannheim: Mannheim, Germany, 2001. (In German)

118. Sheeran, P.; Webb, T.L. The Intention-Behavior Gap. Soc. Pers. Psychol. Compass. 2016, 10, 503-518. [CrossRef] 